\title{
Influence of Rice Residue Management Techniques and Weed Control Treatments on Soil Available Plant Nutrients in Rice-Wheat Cropping System
}

\author{
Amandeep Singh Brar¹, Parmodh Sharma², Charanjit Singh Kahlon ${ }^{3}$, Ujagar Singh Walia1 \\ ${ }^{1}$ Department of Agronomy, Punjab Agricultural University, Ludhiana, India \\ ${ }^{2}$ Economics, Applied Statistics \& International Business Department, New Mexico State University, Las Cruces, NM, USA \\ ${ }^{3}$ Department of Experiment Statistics, AgCenter, Louisiana State University, Baton Rouge, LA, USA \\ Email: sharmap2@gmail.com
}

How to cite this paper: Brar, A.S., Sharma, P., Kahlon, C.S. and Walia, U.S. (2019) Influence of Rice Residue Management Techniques and Weed Control Treatments on Soil Available Plant Nutrients in Rice-Wheat Cropping System. American Journal of Plant Sciences, 10, 55-64.

https://doi.org/10.4236/ajps.2019.101006

Received: October 16, 2018

Accepted: January 6, 2019

Published: January 9, 2019

Copyright $\odot 2019$ by author(s) and Scientific Research Publishing Inc. This work is licensed under the Creative Commons Attribution International License (CC BY 4.0).

http://creativecommons.org/licenses/by/4.0/

\begin{abstract}
Rice-wheat is the predominant cropping system of fertile soils of Indian, Pakistan, Bangladesh and Nepal falling in the alluvial Indo-Gangetic Plains (IGP). Management of rice residues produced after the harvest of rice crop and before sowing of the next wheat crop is a big challenge in that area. Mostly farmers burn rice residues assuming it low profile fodder and of little use. Burning of rice residues deprives the fields from many plant nutrients as they are lost during burning along with environmental pollutions and other issues. A field study was conducted for two consecutive years at the experimental area of the Department of Agronomy, Punjab Agricultural University, Ludhiana (India) to assess the impact of different rice residue management techniques and weed control treatments in wheat on soil available plant nutrients in rice-wheat cropping system. The experiment was laid out in split plot design with three replications. In main plots, five rice residue management treatments viz., no rice residue, rice residue $5 \mathrm{t} \cdot \mathrm{ha}^{-1}$ (surface), rice residue $6 \mathrm{t} \cdot \mathrm{ha}^{-1}$ (surface), rice residue $7 \mathrm{t} \cdot \mathrm{ha}^{-1}$ (surface) and rice residue $5 \mathrm{t} \cdot \mathrm{ha}^{-1}$ (incorporation) were settled and in sub plots, four weed control treatments i.e. clodinafop $60 \mathrm{~g} \cdot \mathrm{ha}^{-1}$, sulfosulfuron $25 \mathrm{~g} \cdot \mathrm{ha}^{-1}$, mesosulfuron + iodosulfuron $12 \mathrm{~g} \cdot \mathrm{ha}^{-1}$ and control (unweeded) were arranged. Results of the study revealed that surface application as well as incorporation of rice residues improved the organic carbon and NPK status than no rice residues. Among the residue management practices, incorporation of rice residues $5 \mathrm{t} \cdot \mathrm{ha}^{-1}$ significantly improved the soil organic carbon, available nitrogen, phosphorus and potassium than no rice residue treatment in the $0-15$ soil layer during both the
\end{abstract}


years. Same trend was observed for $15-30 \mathrm{~cm}$ soil layer but differences were less wide than $0-15 \mathrm{~cm}$ soil layer. Among the weed control treatments, organic carbon was not significantly influenced. Herbicide treated plots registered significantly higher available nitrogen, phosphorus and potassium than control (unweeded) treatment in the $0-15 \mathrm{~cm}$ soil layer during both the years.

\section{Keywords}

Residue Management, Rice Residue, Weed Control

\section{Introduction}

Rice (Oryza sativa L.)-wheat (Triticum aestivum L.) (RW) is the most predominant cropping system of fertile alluvial soils of Indo-Gangetic Plains (IGP) falling in South Asia, a niche area of this system, covering an area of about $12.3 \mathrm{M}$ ha in India, 2.2 M ha in Pakistan, 0.8 M ha in Bangladesh and 0.5 M ha in Nepal [1] [2]. The northwestern (NW) states Punjab and Haryana, "the food bowl of India", a highly productive rice-wheat zone of the Indo-Gangetic Plains of India contributes about two-third of the total food production of the country. But a rice-wheat sequence with total yield of $10-12 \mathrm{t} \cdot \mathrm{ha}^{-1}$ removes more than $300 \mathrm{~kg}$ $\mathrm{N}, 30 \mathrm{~kg} \mathrm{P}$, and $300 \mathrm{~kg} \mathrm{~K} \mathrm{ha}^{-1}$ from the soil [3]. Continuous adoption of same RW cropping system, both crops belonging to the same family, exhaustive nature, and extreme tillage necessities particularly of rice has made the system unrealistic due to the development of hard pan, multi-nutritional deficiencies and destruction of soil structure. Now the signs of fatigue are perceptible. Efforts should be focused to find the solution of the problems affecting the sustainability and profitability of this system. For the suitability of this system, inclusion of organic materials in the soil is must. The scope of leaving the soil fallow for green manuring are diminutive in an era of intensive agriculture. Wheat straw is mostly used as dry fodder for animals, whereas, paddy straw (residues) becomes surplus in the fields as it is of low value fodder for cattle. The leftover paddy residues in the field offer a serious problem during the sowing of the wheat crop. Mostly farmers opt to the burning practice as it is easy and swift alternative to clean the fields. However, this burning practice leads to huge losses of precious organic matter, plant nutrients, creates environmental pollution and also results in fire hazards, etc. Further, this burning practice also reduces the efficacy of herbicides as the ash produced interferes with the applied herbicides particularly root uptake ones, which results in more infestation of weeds and ultimately nutrient mining by weeds [4]. Calculated in economic terms through $\mathrm{N}$ alone, the Punjab farmers are losing Rs. 684 million (approximately $\$ 10$ million) annually by burning paddy straw [5]. For improving soil health and crop productivity, there is an urgent need for in-situ management of rice residues by surface mulching or by incorporating it in soil. Rice residues are potential source of 
organic carbon and plant nutrients for improving soil organic matter dynamics, nutrient cycling and soil physical environment [6]. In nutrient exhaustive rice-wheat cropping system, in-situ management of crop residues as a means of nutrient recycling in the soil plant ecosystem is an essential component for sustaining the productivity as it alters the soil environment, microbial population and activity in soil and subsequently nutrient transformation [7].

Weeds are major menace in the wheat crop which reduces wheat yield and also results in nutrient mining. Regarding the chemical control of weeds, the recommendation of herbicides in wheat is for residue removed situations only. Rice residues can interfere with the herbicides physically or in the form of ash or organic carbon produced from rice residues. The behavior of herbicides may vary under residue incorporation, surface retention and residue removal situations, which may alter the nutrient uptake by crop as well as by weeds and ultimately the soil availability of plant nutrients. Therefore, in the light of such complexities, the present investigation was undertaken to find out the effect of rice residue management techniques and weed control treatments on soil available plant nutrients.

\section{Materials and Methods}

The experiment was conducted at the experimental area of the department of Agronomy, Punjab Agricultural University, Ludhiana, Punjab (India) during Rabi season of 2004-05 and 2005-06. The experiment was conducted in split plot design with three replications. In main plots, five rice residue management treatments i.e. no rice residue, rice residue $5 \mathrm{t} \cdot \mathrm{ha}^{-1}$ (surface), rice residue $6 \mathrm{t} \cdot \mathrm{ha}^{-1}$ (surface), rice residue $7 \mathrm{t} \cdot \mathrm{ha}^{-1}$ (surface) and rice residue $5 \mathrm{t} \cdot \mathrm{ha}^{-1}$ (incorporation) were allotted, whereas, in sub plots, four weed control treatments i.e. clodinafop $60 \mathrm{~g} \cdot \mathrm{ha}^{-1}$, sulfosulfuron $25 \mathrm{~g} \cdot \mathrm{ha}^{-1}$, mesosulfuron + iodosulfuron $12 \mathrm{~g} \cdot \mathrm{ha}^{-1}$ and control (unweeded) were arranged. Soil analysis before the start of the experiment showed (Table 1) that soil of the experimental field was loamy sand in texture, normal in soil reaction (7.3) and electrical conductivity $\left(0.26 \mathrm{dS} \cdot \mathrm{m}^{-1}\right)$, medium in organic carbon $\left(4.2 \mathrm{~g} \cdot \mathrm{kg}^{-1}\right)$, available phosphorus $\left(18.6 \mathrm{~kg} \cdot \mathrm{ha}^{-1}\right)$ as well as potassium $\left(150 \mathrm{~kg} \cdot \mathrm{ha}^{-1}\right)$ and low in available nitrogen $\left(230 \mathrm{~kg} \cdot \mathrm{ha}^{-1}\right)$.

In the rice residue incorporation treatment, rice residues $5 \mathrm{t} \cdot \mathrm{ha}^{-1}$ were incorporated using disc harrow and cultivators, however, other plots of no rice residue and surface mulching treatments were kept as such after the harvest of paddy crop i.e. zero till. The sowing of wheat crop in incorporation treatment was done with tractor drawn convention drill whereas in no rice residue and surface application of rice residue treatments, sowing of wheat crop was done with zero till drill using seed rate of $100 \mathrm{~kg} \cdot \mathrm{ha}^{-1}$. Chopped and sun-dried rice residues were spread uniformly after wheat sowing on the same day as per the treatments of 5 , 6 and $7 \mathrm{t} \cdot \mathrm{ha}^{-1}$. Following the recommended package of practices, $\mathrm{N}\left(125 \mathrm{~kg} \cdot \mathrm{ha}^{-1}\right)$ and $\mathrm{P}_{2} \mathrm{O}_{5}\left(60 \mathrm{~kg} \cdot \mathrm{ha}^{-1}\right)$ were applied through urea and diammonium phosphate (DAP), respectively. Half of the dose of nitrogen and full dose of phosphorus were applied at the time of sowing while the remaining half dose of $\mathrm{N}$ was 
Table 1. Physio-chemical characteristics of the experimental field.

\begin{tabular}{|c|c|c|c|}
\hline & \multicolumn{2}{|c|}{ Values } & \multirow{2}{*}{ Analytical method } \\
\hline & $0-15 \mathrm{~cm}$ & $15-30 \mathrm{~cm}$ & \\
\hline \multicolumn{4}{|l|}{ A. Chemical analysis } \\
\hline $\mathrm{pH}$ & 7.32 & 7.37 & $\begin{array}{l}\text { Beckman's glass electronic } \\
\text { pH meter in 1:2 soil: } \\
\text { water suspension [11] }\end{array}$ \\
\hline $\mathrm{EC}\left(\mathrm{dS} \cdot \mathrm{m}^{-1}\right)$ & 0.26 & 0.28 & $\begin{array}{l}\text { 1:2 soil water suspension } \\
\text { with solubridge [11] }\end{array}$ \\
\hline $\begin{array}{l}\text { Organic carbon } \\
\quad\left(\mathrm{g} \cdot \mathrm{kg}^{-1}\right)\end{array}$ & 4.2 & 3.3 & $\begin{array}{l}\text { Walkley and Black's } \\
\text { rapid titration method [11] }\end{array}$ \\
\hline $\begin{array}{l}\text { Available N } \\
\left(\mathrm{kg} \cdot \mathrm{ha}^{-1}\right)\end{array}$ & 230 & 176 & $\begin{array}{l}\text { Modified alkaline potassium } \\
\text { permanganate method [9] }\end{array}$ \\
\hline $\begin{array}{l}\text { Available P } \\
\left(\mathrm{kg} \cdot \mathrm{ha}^{-1}\right)\end{array}$ & 18.6 & 16.0 & $\begin{array}{l}0.5 \mathrm{~N} \text { sodium bicarbonate } \\
\text { extractable } \mathrm{P} \text { by Olsen's method [10] }\end{array}$ \\
\hline $\begin{array}{l}\text { Available K } \\
\left(\mathrm{kg} \cdot \mathrm{ha}^{-1}\right)\end{array}$ & 150 & 146 & $\begin{array}{l}\text { Ammonium acetate } \\
\text { extractable } \mathrm{K}[11]\end{array}$ \\
\hline \multicolumn{4}{|c|}{ B. Mechanical analysis } \\
\hline Sand (\%) & 76.8 & 75.8 & \multirow{3}{*}{$\begin{array}{l}\text { International } \\
\text { pipette method [19] }\end{array}$} \\
\hline Silt (\%) & 9.3 & 9.1 & \\
\hline Clay (\%) & 13.8 & 14.8 & \\
\hline C. Textural class & Loamy sand & Loamy sand & \\
\hline
\end{tabular}

applied as broadcast after first irrigation (21 DAS). Post-emergence application of clodinafop, sulfosulfuron and mesosulfuron + iodosulfuron was made 35 days after sowing (DAS) at their respective doses.

After the harvest of wheat crop, soil samples were collected from two depths viz., $0-15 \mathrm{~cm}$ and $15-30 \mathrm{~cm}$. The soil samples were dried under shade, ground and passed through $2 \mathrm{~mm}$ sieve and analyzed for determination of organic carbon, available nitrogen, phosphorus and potassium. Organic carbon was estimated using Walkley and Black's rapid titration method as described by [8] Available nitrogen was determined by modified alkaline potassium permanganate method as described by [9]. Available phosphorus was determined by method prescribed by [10]. Available potassium was extracted with neutral normal ammonium acetate solution as described by [11] using flame photometer. The data collected on various aspects of the investigations were statistically analyzed as prescribed by [12] and adapted by [13] in statistical package CPCS-1. The comparisons were made at $5 \%$ level of significance.

\section{Results and Discussion}

\subsection{Organic Carbon}

Soil organic carbon is the back bone of soil fertility. It was significantly influenced by different rice residue management techniques at both the soil depths 
during both the years. During first year of study, in $0-15 \mathrm{~cm}$ soil layer, soil organic carbon was significantly improved with surface application (5, 6 and 7 $\left.\mathrm{t} \cdot \mathrm{ha}^{-1}\right)$ as well as incorporation of rice residue $\left(5 \mathrm{t} \cdot \mathrm{ha}^{-1}\right)$ treatments than no rice residue treatment (Table 2). Among the rice residue application treatments, incorporation of rice residue $\left(5 \mathrm{t} \cdot \mathrm{ha}^{-1}\right)$ significantly improved soil organic carbon content than surface application of rice residue treatments $\left(5,6\right.$ and $\left.7 \mathrm{t} \cdot \mathrm{ha}^{-1}\right)$. Among the surface retention of rice residue treatments, soil organic carbon content was significantly improved with higher load of rice residue $\left(7 \mathrm{t} \cdot \mathrm{ha}^{-1}\right)$ than lower load of rice residue ( $\left.5 \mathrm{t} \cdot \mathrm{ha}^{-1}\right)$. During second year of study, again surface application as well as rice residue incorporation treatments registered significantly higher organic carbon content than no rice residue treatment. However, this time rice residue incorporation $\left(5 \mathrm{t} \cdot \mathrm{ha}^{-1}\right)$ treatment being statistically at par with surface application of rice residue ( 6 and $7 \mathrm{t} \cdot \mathrm{ha}^{-1}$ ) showed higher organic carbon content only than least load of surface application treatment $\left(5 \mathrm{t} \cdot \mathrm{ha}^{-1}\right)$. All the surface applications of rice residue treatments were statistically at par with each other. In the $15-30 \mathrm{~cm}$ soil layer, during first year of study, incorporation as well as surface retention of rice residue treatments registered significantly higher organic carbon content than no rice residues. Further, incorporation of rice residues $\left(5 \mathrm{t} \cdot \mathrm{ha}^{-1}\right)$ recorded significantly higher organic carbon content than surface application of rice residues $\left(5,6\right.$ and $\left.7 \mathrm{t} \cdot \mathrm{ha}^{-1}\right)$. Similar trend was observed during second year of investigation. Slight improvement was observed in organic carbon content under all the treatments during second year of study

Table 2. Soil organic carbon and available nitrogen as influenced by rice residue management techniques and weed control treatments.

\begin{tabular}{|c|c|c|c|c|c|c|c|c|}
\hline \multirow{3}{*}{ Treatment } & \multicolumn{4}{|c|}{ Organic carbon $\left(\mathrm{g} \cdot \mathrm{kg}^{-1}\right)$} & \multicolumn{4}{|c|}{ Available Nitrogen $\left(\mathrm{kg} \cdot \mathrm{ha}^{-1}\right)$} \\
\hline & \multicolumn{2}{|c|}{ 2004-05 } & \multicolumn{2}{|c|}{ 2005-06 } & \multicolumn{2}{|c|}{ 2004-05 } & \multicolumn{2}{|c|}{ 2005-06 } \\
\hline & $0-15 \mathrm{~cm}$ & $15-30 \mathrm{~cm}$ & $0-15 \mathrm{~cm}$ & $15-30 \mathrm{~cm}$ & $0-15 \mathrm{~cm}$ & $15-30 \mathrm{~cm}$ & $0-15 \mathrm{~cm}$ & $15-30 \mathrm{~cm}$ \\
\hline \multicolumn{9}{|c|}{ Rice residue management techniques } \\
\hline No rice residue & $4.0^{\mathrm{d}}$ & $3.0^{c}$ & $3.9^{c}$ & $3.0^{c}$ & $224^{\mathrm{b}}$ & $171^{\mathrm{b}}$ & $226^{\mathrm{b}}$ & $172^{\mathrm{b}}$ \\
\hline Rice residue $5 \mathrm{t} \cdot \mathrm{ha}^{-1}$ (surface) & $4.2^{\mathrm{c}}$ & $3.1^{\mathrm{b}}$ & $4.3^{\mathrm{b}}$ & $3.2^{\mathrm{b}}$ & $227^{\mathrm{ab}}$ & $172^{\mathrm{ab}}$ & $233^{\mathrm{a}}$ & $176^{\mathrm{a}}$ \\
\hline Rice residue $6 \mathrm{t} \cdot \mathrm{ha}^{-1}$ (surface) & $4.3^{\mathrm{bc}}$ & $3.1^{\mathrm{b}}$ & $4.4^{\mathrm{ab}}$ & $3.2^{\mathrm{b}}$ & $228^{\mathrm{ab}}$ & $173^{\mathrm{ab}}$ & $234^{\mathrm{a}}$ & $176^{\mathrm{a}}$ \\
\hline Rice residue $7 \mathrm{t} \cdot \mathrm{ha}^{-1}$ (surface) & $4.4^{\mathrm{b}}$ & $3.1^{\mathrm{b}}$ & $4.5^{\mathrm{ab}}$ & $3.2^{\mathrm{b}}$ & $230^{\mathrm{ab}}$ & $174^{\mathrm{ab}}$ & $235^{\mathrm{a}}$ & $177^{\mathrm{a}}$ \\
\hline Rice residue $5 \mathrm{t} \cdot \mathrm{ha}^{-1}$ (incorp.) & $4.6^{\mathrm{a}}$ & $3.3^{\mathrm{a}}$ & $4.6^{\mathrm{a}}$ & $3.5^{\mathrm{a}}$ & $234^{\mathrm{a}}$ & $176^{\mathrm{a}}$ & $237^{\mathrm{a}}$ & $177^{\mathrm{a}}$ \\
\hline $\mathrm{C} \mathrm{D}(\mathrm{P}=0.05)$ & 0.2 & 0.1 & 0.3 & 0.2 & 8.0 & 4.7 & 6.9 & 4.0 \\
\hline \multicolumn{9}{|c|}{ Weed control treatments } \\
\hline Clodinafop $60 \mathrm{~g} \cdot \mathrm{ha}^{-1}$ & $4.3^{\mathrm{a}}$ & $3.1^{\mathrm{a}}$ & $4.3^{\mathrm{a}}$ & $3.2^{\mathrm{a}}$ & $229^{\mathrm{ab}}$ & $173^{\mathrm{ab}}$ & $233^{\mathrm{a}}$ & $175^{\mathrm{ab}}$ \\
\hline Sulfosulfuron $25 \mathrm{~g} \cdot \mathrm{ha}^{-1}$ & $4.3^{\mathrm{a}}$ & $3.2^{\mathrm{a}}$ & $4.4^{\mathrm{a}}$ & $3.2^{\mathrm{a}}$ & $228^{\mathrm{ab}}$ & $173^{\mathrm{ab}}$ & $235^{\mathrm{a}}$ & $176^{\mathrm{ab}}$ \\
\hline Meso + iodo $12 \mathrm{~g} \cdot \mathrm{ha}^{-1}$ & $4.4^{\mathrm{a}}$ & $3.2^{\mathrm{a}}$ & $4.4^{\mathrm{a}}$ & $3.3^{\mathrm{a}}$ & $231^{\mathrm{a}}$ & $175^{\mathrm{a}}$ & $236^{\mathrm{a}}$ & $177^{\mathrm{a}}$ \\
\hline Control & $4.2^{\mathrm{a}}$ & $3.0^{\mathrm{a}}$ & $4.3^{\mathrm{a}}$ & $3.1^{\mathrm{a}}$ & $227^{\mathrm{b}}$ & $172^{\mathrm{b}}$ & $228^{\mathrm{b}}$ & $174^{\mathrm{b}}$ \\
\hline $\mathrm{C} \mathrm{D}(\mathrm{P}=0.05)$ & NS & NS & NS & NS & 3.7 & 2.8 & 4.2 & 2.9 \\
\hline
\end{tabular}


than first year. It is evident from the results of the study that addition of carbonaceous substances in the form of rice residue favored higher soil organic carbon content. Further, incorporation of rice residues showed higher soil organic carbon content than surface application of rice residues probably due to more decay of rice residue in incorporation treatment than surface application treatment. Similarly, among the surface application of rice residue treatments, higher load of rice residue added more of carbonaceous substances resulting in higher organic carbon content. Improvement in soil organic carbon content with the addition of crop residues as compared to crop residue removal situations [14] [15].

Among the different weed control treatments, soil organic carbon content was not significantly influenced at both the soil depths during both the years. Variation in soil organic carbon content might be due to variation in total root biomass of wheat and weeds.

\subsection{Available Nitrogen}

Soil available nitrogen is significantly influenced by the addition and mineralization of crop residues and nutrient uptake by plants. Further, load and placement of crop residues also significantly influence the available nitrogen in the soil. The results of investigation revealed that during first year, available nitrogen was significantly improved with the incorporation of rice residue $\left(5 \mathrm{t} \cdot \mathrm{ha}^{-1}\right)$ than without adding any crop residues both in the $0-15 \mathrm{~cm}$ and $15-30 \mathrm{~cm}$ soil layers (Table 2). Application of residues as surface mulch also improved the available nitrogen as compared to no rice residue (removed) treatments but the differences were not up to the level of significance. During second year, soil available nitrogen was significantly improved with all the residue application treatments (surface retention as well as incorporation) than rice residue removal treatment at both the soil depths $(0-15 \mathrm{~cm}$ and $15-30 \mathrm{~cm})$. Higher available nitrogen content with application of rice residues could be attributed to addition of crop residue and reduction of nitrogen loss in residues incorporated plots by forming organo-mineral complexes [16]. Further, improvement in available nitrogen in soil under all the rice residue treatments during second year might be due to addition of crop residues for consecutive two years in the same plots. Some studies also found improvement in soil nitrogen with the addition of crop residues as compared to crop residue removal [16] [17].

Weed control treatments also significantly influenced the available nitrogen in the soil. Mesosulfuron + iodosulfuron $12.0 \mathrm{~g} \cdot \mathrm{ha}^{-1}$, being statistically at par with other herbicides clodinafop $60 \mathrm{~g} \cdot \mathrm{ha}^{-1}$ and sulfosulfuron $25 \mathrm{~g} \cdot \mathrm{ha}^{-1}$ recorded significantly higher available nitrogen than unweeded control treatment during both the year at both the soil depths except at $0-15 \mathrm{~cm}$ soil layer during second year when all the herbicide application treatments recorded significant edge over unweeded control. At the end of second crop season, available nitrogen content of soil was slightly improved as compared to the initial values. It was reported that higher cumulative nitrogen uptake by crop and weeds in unweeded control than herbicide application treatments. More nutrient mining by crop + weeds in 
unweeded control treatment might be the probable reason for lower nitrogen content in soil than herbicide application treatments [18].

\subsection{Available Phosphorus}

The available phosphorus content of soil was also significantly influenced by different rice residue management techniques. During first year of study, available phosphorus content at $0-15 \mathrm{~cm}$ soil layer was significantly higher with incorporation of rice residue $\left(5 \mathrm{t} \cdot \mathrm{ha}^{-1}\right)$ and highest load of surface application of rice residue $\left(7 \mathrm{t} \cdot \mathrm{ha}^{-1}\right)$ than rice residue removal treatment (Table 3). Although slight improvement in available phosphorus content in soil was observed with surface application of rice residues ( 5 and $6 \mathrm{t} \cdot \mathrm{ha}^{-1}$ ) but it was not to the level of significance. At lower depth $(15-30 \mathrm{~cm})$, rice residue incorporation $\left(5 \mathrm{t} \cdot \mathrm{ha}^{-1}\right)$ treatment registered significantly higher available phosphorus content than no rice residue application treatment as well as surface application of rice residue treatments. Surface application of rice residue at 5, 6 and $7 \mathrm{t} \cdot \mathrm{ha}^{-1}$ did not exhibit any significant difference than no rice residue application treatment at lower depth of $15-30 \mathrm{~cm}$. During second year of study, at $0-15 \mathrm{~cm}$ soil layer, rice residue incorporation $\left(5 \mathrm{t} \cdot \mathrm{ha}^{-1}\right)$ treatment along with surface application of rice residue at 6 and $7 \mathrm{t} \cdot \mathrm{ha}^{-1}$ recorded significantly higher available phosphorus content than no rice residue treatment. At lower depth of $15-30 \mathrm{~cm}$, incorporation of rice residue $\left(5 \mathrm{t} \cdot \mathrm{ha}^{-1}\right)$ along with higher load of surface application of rice residue $\left(7 \mathrm{t} \cdot \mathrm{ha}^{-1}\right)$ recorded significantly higher available phosphorus content than

Table 3. Soil available phosphorus and potassium as influenced by rice residue management techniques and weed control treatments.

\begin{tabular}{|c|c|c|c|c|c|c|c|c|}
\hline \multirow{3}{*}{ Treatment } & \multicolumn{4}{|c|}{ Available Phosphorus $\left(\mathrm{kg} \cdot \mathrm{ha}^{-1}\right)$} & \multicolumn{4}{|c|}{ Available Potassium $\left(\mathrm{kg} \cdot \mathrm{ha}^{-1}\right)$} \\
\hline & \multicolumn{2}{|c|}{ 2004-05 } & \multicolumn{2}{|c|}{ 2005-06 } & \multicolumn{2}{|c|}{ 2004-05 } & \multicolumn{2}{|c|}{$2005-06$} \\
\hline & $0-15 \mathrm{~cm}$ & $15-30 \mathrm{~cm}$ & $0-15 \mathrm{~cm}$ & $15-30 \mathrm{~cm}$ & $0-15 \mathrm{~cm}$ & $15-30 \mathrm{~cm}$ & $0-15 \mathrm{~cm}$ & $15-30 \mathrm{~cm}$ \\
\hline \multicolumn{9}{|c|}{ Rice residue management techniques } \\
\hline No rice residue & $18.6^{\mathrm{b}}$ & $15.7^{\mathrm{b}}$ & $18.7^{\mathrm{bc}}$ & $15.8^{\mathrm{c}}$ & $150^{\mathrm{b}}$ & $146^{\mathrm{b}}$ & $151^{\mathrm{b}}$ & $145^{\mathrm{b}}$ \\
\hline Rice residue $5 \mathrm{t} \cdot \mathrm{ha}^{-1}$ (surface) & $18.9^{\mathrm{ab}}$ & $15.9^{\mathrm{b}}$ & $19.1^{\mathrm{bc}}$ & $16.2^{\mathrm{bc}}$ & $152^{\mathrm{ab}}$ & $146^{\mathrm{ab}}$ & $153^{\mathrm{ab}}$ & $149^{\mathrm{a}}$ \\
\hline Rice residue $6 \mathrm{t} \cdot \mathrm{ha}^{-1}$ (surface) & $19.0^{\mathrm{ab}}$ & $16.0^{\mathrm{b}}$ & $19.3^{\mathrm{a}}$ & $16.4^{\mathrm{bc}}$ & $153^{\mathrm{ab}}$ & $147^{\mathrm{ab}}$ & $154^{\mathrm{ab}}$ & $150^{\mathrm{a}}$ \\
\hline Rice residue $7 \mathrm{t} \cdot \mathrm{ha}^{-1}$ (surface) & $19.2^{\mathrm{a}}$ & $16.2^{\mathrm{b}}$ & $19.7^{\mathrm{a}}$ & $16.8^{\mathrm{ab}}$ & $154^{\mathrm{ab}}$ & $148^{\mathrm{ab}}$ & $155^{\mathrm{a}}$ & $152^{\mathrm{a}}$ \\
\hline Rice residue $5 \mathrm{t} \cdot \mathrm{ha}^{-1}$ (incorp.) & $19.4^{\mathrm{a}}$ & $17.1^{\mathrm{a}}$ & $19.8^{\mathrm{a}}$ & $17.3^{\mathrm{a}}$ & $155^{\mathrm{a}}$ & $150^{\mathrm{a}}$ & $156^{\mathrm{a}}$ & $152^{\mathrm{a}}$ \\
\hline $\mathrm{C} \mathrm{D}(\mathrm{P}=0.05)$ & 0.6 & 0.8 & 0.6 & 0.9 & 4.3 & 3.6 & 3.9 & 3.7 \\
\hline \multicolumn{9}{|c|}{ Weed control treatments } \\
\hline Clodinafop $60 \mathrm{~g} \cdot \mathrm{ha}^{-1}$ & $19.1^{\mathrm{a}}$ & $16.2^{\mathrm{a}}$ & $19.5^{\mathrm{a}}$ & $16.5^{\mathrm{a}}$ & $153^{\mathrm{a}}$ & $147^{\mathrm{a}}$ & $153^{\mathrm{bc}}$ & $149^{\mathrm{a}}$ \\
\hline Sulfosulfuron $25 \mathrm{~g} \cdot \mathrm{ha}^{-1}$ & $19.2^{\mathrm{a}}$ & $16.2^{\mathrm{a}}$ & $19.7^{\mathrm{a}}$ & $16.5^{\mathrm{a}}$ & $153^{\mathrm{a}}$ & $148^{\mathrm{a}}$ & $155^{\mathrm{ab}}$ & $150^{\mathrm{a}}$ \\
\hline Meso + iodo $12 \mathrm{~g} \cdot \mathrm{ha}^{-1}$ & $19.4^{\mathrm{a}}$ & $16.3^{\mathrm{a}}$ & $19.7^{\mathrm{a}}$ & $16.6^{\mathrm{a}}$ & $155^{\mathrm{a}}$ & $148^{\mathrm{a}}$ & $156^{\mathrm{a}}$ & $150^{\mathrm{a}}$ \\
\hline Control (unweeded) & $18.4^{\mathrm{b}}$ & $16.0^{\mathrm{a}}$ & $18.5^{\mathrm{b}}$ & $16.4^{\mathrm{a}}$ & $150^{\mathrm{b}}$ & $146^{\mathrm{a}}$ & $151^{\mathrm{c}}$ & $149^{\mathrm{a}}$ \\
\hline $\mathrm{C} \mathrm{D}(\mathrm{P}=0.05)$ & 0.5 & NS & 0.6 & NS & 2.8 & NS & 2.6 & NS \\
\hline
\end{tabular}


rice residue removal treatment. It was reported that addition of oxidizable materials promotes process of reduction and thus increase the content of available phosphorus in soil. Highest available phosphorus content with rice residue incorporation treatment might be due to decomposition of rice residue at faster rate than surface application of rice residue treatment [16]. Further, lowest available phosphorus content with no rice residue treatment might be due to removal of oxidizable material from soil surface. Studies also observed improvement in available phosphorus with application of crop residue as compared to residue removal treatment [15] [16].

Among the weed control treatments, available phosphorus content was significantly influenced by only at $0-15 \mathrm{~cm}$ soil layer during both the years, however at lower depth of $15-30 \mathrm{~cm}$ the difference was not to the level of significance. All the herbicide application treatments viz., mesosulfuron + iodosulfuron 12 $\mathrm{g} \cdot \mathrm{ha}^{-1}$, sulfosulfuron $25 \mathrm{~g} \cdot \mathrm{ha}^{-1}$, clodinafop $60 \mathrm{~g} \cdot \mathrm{ha}^{-1}$ showed significantly higher available phosphorus content than unweeded control treatment at $0-15 \mathrm{~cm}$ soil layer during both the year of investigation. Higher nutrient mining by crop + weeds in untreated plots as compared to herbicide treated plots [18]. Similarly in this study, higher available phosphorus content in herbicide application treatments might be due to less mining of phosphorus by weeds as compared to unweeded control.

\subsection{Available Potassium}

The perusal of data presented in Table 3 revealed that potassium, another major plant nutrient was also significantly influenced by rice residue management treatments. Likewise nitrogen and phosphorus, available potassium in $0-15 \mathrm{~cm}$ soil layer was highest in rice residue incorporation $\left(5 \mathrm{t} \cdot \mathrm{ha}^{-1}\right)$ treatment which being statistically at par with surface application of rice residue treatments $(5,6$ and $7 \mathrm{t} \cdot \mathrm{ha}^{-1}$ ) recorded significantly higher available potassium in soil than rice residue removal treatment during both the years. Further, surface application of rice residue $7 \mathrm{t} \cdot \mathrm{ha}^{-1}$ also recorded significantly higher available potassium content than no rice residue treatment during second year of study. At $15-30 \mathrm{~cm}$ soil depth, during first year, rice residue incorporation $\left(5 \mathrm{t} \cdot \mathrm{ha}^{-1}\right)$ alone recorded significantly higher available potassium content than no rice residue treatment, however, during second year of study, all the rice residue application treatment including surface application 5, 6 and $7 \mathrm{t} \cdot \mathrm{ha}^{-1}$ as well as rice residue incorporation $5 \mathrm{t} \cdot \mathrm{ha}^{-1}$ treatments registered significantly higher available potassium in soil. No rice residue treatment registered the least available potassium content among the different rice residue management treatments at both the soil depths during both the years of investigation. Application of rice residue as mulch as well as incorporation increased the available $\mathrm{K}$ content of soil after the harvest of second season crop than the initial available potassium content in soil. It was observed that higher available potassium content with the application of residues as residues contains relatively higher potassium content [15] [16]. 
Among the different weed control treatments, at $0-15 \mathrm{~cm}$ soil layer, all the herbicide treatments viz., mesosulfuron + iodosulfuron $12 \mathrm{~g} \cdot \mathrm{ha}^{-1}$, sulfosulfuron $25 \mathrm{~g} \cdot \mathrm{ha}^{-1}$, clodinafop $60 \mathrm{~g} \cdot \mathrm{ha}^{-1}$ recorded significantly higher available potassium than unweeded control during first year, however, during second year, mesosulfuron + iodosulfuron $12 \mathrm{~g} \cdot \mathrm{ha}^{-1}$ and sulfosulfuron $25 \mathrm{~g} \cdot \mathrm{ha}^{-1}$ showed significantly higher available potassium content than no herbicide (unweeded control) treatment. At 15 - $30 \mathrm{~cm}$ soil layer, during both the year, slight improvement in available potassium was observed with herbicide application treatment over unweeded control but the differences were not up to the level of significance. Control (unweeded) registered the least available potassium among the weed control treatment as more of potassium might be taken by weeds and crop collectively in unweeded (control) as compared to herbicidal treatments [18].

\section{Conclusion}

The present investigation revealed that incorporation or surface application of rice residues significantly improved the soil organic carbon and soil available NPK as compared to rice residue removal. Further, incorporation of rice residues was more beneficial than surface application of rice residues. Application of herbicides also played important role in sustaining soil available NPK by reducing nutrient mining by weeds, thus improving soil available NPK over unweeded control.

\section{Conflicts of Interest}

The authors declare no conflicts of interest regarding the publication of this paper.

\section{References}

[1] Ladha, J., Dawe, D., Pathak, H., Padre, A., Yadav, R., Singh, B., Singh, Y., Singh, Y., Singh, P. and Kundu, A. (2003) How Extensive Are Yield Declines in Long-Term Rice-Wheat Experiments in Asia? Field Crops Research, 81, 159-180. https://doi.org/10.1016/S0378-4290(02)00219-8

[2] Timsina, J. and Connor, D.J. (2001) Productivity and Management of Rice-Wheat Cropping Systems: Issues and Challenges. Field Crops Research, 69, 93-132. https://doi.org/10.1016/S0378-4290(00)00143-X

[3] Singh, Y. and Singh, B. (2001) Efficient Management of Primary Nutrients in the Rice-Wheat System. Journal of Crop Production, 4, 23-85. https://doi.org/10.1300/J144v04n01_02

[4] Brar, A.S. and Walia, U. (2007) Influence of Planting Techniques and Weed Control Treatments on Nutrient Uptake by P. Minor Retz and Broadleaf Weeds in Wheat (Triticum aestivum L.). Indian Journal of Weed Science, 39, 55-61.

[5] Sidhu, B.S., Rupela, O.P., Gopalakrishnan, S. and Beri, V. (1997) Searching Alternatives To Burning Rice Straw. In: Proceedings of the Third Agricultural Science Congress, 12-15 March 1997, PAU, Ludhiana.

[6] Samra, J.S., Singh, B. and Kumar, K. (2003) Managing Crop Residues in the Rice-Wheat System of the Indo-Gangetic Plain. Improving the Productivity and 
Sustainability of Rice-Wheat Systems: Issues and Impacts, 173-195.

[7] Kumar, K. and Goh, K. (1999) Crop Residues and Management Practices: Effects on Soil Quality, Soil Nitrogen Dynamics, Crop Yield, and Nitrogen Recovery. Advances in Agronomy, 68, 197-319. https://doi.org/10.1016/S0065-2113(08)60846-9

[8] Walkley, A. and Black, I.A. (1934) An Examination of the Degtjareff Method for Determining Soil Organic Matter, and a Proposed Modification of the Chromic Acid Titration Method. Soil Science, 37, 29-38. https://doi.org/10.1097/00010694-193401000-00003

[9] Subbaiah, V. and Asija, G. (1956) A Rapid Procedure for Utilization of Available Nitrogen in Soil. Current Science, 26, 258-260.

[10] Olsen, S.R. (1954) Estimation of Available Phosphorus in Soils by Extraction with Sodium Bicarbonate. United States Department of Agriculture; Washington.

[11] Jackson, M. (1967) Soil Chemical Analysis. Prentice Hall of India, New Delhi.

[12] Cochran, W. and Cox, G. (1962) Experimental Designs. Asia Publishing House, Bombay.

[13] Cheema, H. and Singh, B. (1991) Software Statistical Package CPCS-1. Department of Statistics, Punjab Agric University, Ludhiana.

[14] Lanjewar, M., Shelke, D., Jadhao, S. and Hiwase, B. (1992) Studies on Effect of Incorporation of Rice Straw in Soil on Its Properties, Rice Yield and Its Residual Effect on Succeeding Chickpea. Journal of Soils \& Crops, 2, 52-55.

[15] Kachroo, D., Dixit, A.K. and Bali, A.S. (2006) Influence of Crop Residue, Flyash and Varying Starter Dosages on Growth, Yield and Soil Characteristics in Rice (Oryza sativa)-Wheat (Triticum aestivum) Cropping System under Irrigated Conditions of Jammu Region. Indian Journal of Agricultural Sciences, 76, 3.

[16] Das, K., Medhi, D. and Guha, B. (2003) Application of Crop Residues in Combination with Chemical Fertilizers for Sustainable Productivity in Rice (Oryza sativa)-Wheat (Triticum aestivum) System. Indian Journal of Agronomy, 48, 8-11.

[17] Kharub, A., Sharma, R., Mongia, A., Chhokar, R., Tripathi, S. and Sharma, V. (2004) Effect of Rice (Oryza sativa) Straw Removal, Burning and Incorporation on Soil Properties and Crop Productivity under Rice-Wheat (Triticum aestivum) System. Indian Journal of Agricultural Science, 74, 295-299.

[18] Brar, A.S. and Walia, U. (2008) Effect of Rice Residue Management Techniques and Herbicides on Nutrient Uptake by Phalaris Minor Retz. and Wheat (Triticum aestivum L.). Indian Journal of Weed Science, 40, 121-127.

[19] Piper, C.S. (1966) Soil and Plant Analysis. Hans Publishers, Bombay. 